\title{
O CONTEXTO PÓS-DEMARCATÓRIO: QUANDO SE TRATA DE REDEFINIR O CONTROLE SOCIAL SOBRE OS RECURSOS NATURAIS E BENS CULTURAIS
}

\author{
ANDRÉ LUIS DE OLIVEIRA ARAÚJO ${ }^{1}$ \\ Universidade de Córdoba \\ EDSON HELY SILVA ${ }^{2}$ \\ $U F P E$
}

DAVID GALLAR HERNÁNDEZ ${ }^{3}$

Universidade de Córdoba

\begin{abstract}
RESUMO:O artigo apresenta formulações que se desdobram da síntese teórica para a reorganização social de grupos étnicos elaboradas pelo antropólogo João Pacheco de Oliveira, em especial quando atrelada à conquista de garantias fundiárias. A intenção, neste momento, foi avolumar a discussão desse lugar teórico estabelecido pelo supracitado autor para aprofundar a ideia da redefinição do controle social sobre os recursos ambientais. A expectativa é que, ao explorar tais concepções, seja possivel contribuir para os estudos voltados à compreensão de movimentos identitários socioespaciais reivindicatórios, gerando aportes para interpretações do momento pós-demarcatório, dialogando com o que é denominado atualmente de gestão ambiental e territorial em terras indígenas. Neste ensaio, formulou-se a ideia da redefinição do controle social sobre os recursos naturais e bens culturais como fenômeno relevante nas interpretações de processos de reorganização social de repercussão territorial de grupos sociais e étnicos.
\end{abstract}

PALAVRAS-CHAVE: comunidades tradicionais; povos indígenas; territorialização; etnogênese; Xukuru do Ororubá.

\footnotetext{
${ }^{1}$ Doutorando do programa de Agroecologia da Universidade de Córdoba, Espanha. Possui graduação em Geografia, Bacharel pela Universidade do Estado do Rio de Janeiro (2005) e Licenciatura pelo Centro Universitário de Brasília (2010). Especialista em Indigenismo e Desenvolvimento Sustentável pela Universidade de Brasília (2009) e Mestre em Agroecologia pela Universidad Internacional de Andalucía (2011). É analista em Reforma e Desenvolvimento Agrário vinculado ao Instituto Nacional de Colonização e Reforma Agrária - INCRA, e atualmente encontra-se na Subsecretaria de Agricultura Familiar da Secretaria Especial de Agricultura Familiar e do Desenvolvimento Agrário da Casa Civil. E-mail: andredearaujo@gmail.com .

${ }^{2}$ Professor Titular de História do Colégio de Aplicação da UFPE. Pós-Doutor em História na UFRJ (2013). Doutor em História Social pela UNICAMP (2008) Mestre em História pela UFPE (1995). Professor no Programa de Pós-Graduação em História/UFCG (Campina Grande/PB) e no PROFHISTÓRIA/UFPE.Email: edson.edsilva@hotmail.com .

${ }^{3}$ Profesor e investigador del Instituto de Sociología y Estudios Campesinos (ISEC) de la Universidad de Córdoba -departamento de Ciencias Sociales y Humanidades, área Sociología. E-mail: david.gallar@uco.es.
} 


\begin{abstract}
The article presents formulations that unfold from the theoretical synthesis to the social reorganization of ethnic groups elaborated by the anthropologist João Pacheco de Oliveira, especially when linked to the conquest of land guarantees. The intention, at this point, was to increase the discussion of this theoretical stance established by the aforementioned author, in order to deepen the notion of redefining social control over environmental resources. The expectation is, in exploring such conceptions, to contribute to studies aimed at understanding the claiming socio-spatial identity movements, generating contributions to interpretations of the postdemarcation moment, allowing dialogue with what is currently termed environmental and territorial management in indigenous lands. In this essay, the notion of a redefined social control over natural resources and cultural goods was formulated as a relevant phenomenon in the interpretations of social reorganization processes with a territorial repercussion of social and ethnic groups.
\end{abstract}

KEYWORDS: traditional communities; indigenous people; territorialization; ethnogenesis; Xukuru do Ororubá.

\title{
Uma breve contextualização dos debates
}

Apesar do Brasil ainda ostentar um grande déficit em relação à demarcação de terras indígenas e de outras populações nomeadas tradicionais, nas últimas décadas têm ganhado força as questões próprias do contexto pós-demarcatório. A criação do Instituto Chico Mendes de Conservação da Biodiversidade, no ano de 2007, com a finalidade de executar as políticas relativas ao uso sustentável dos recursos naturais renováveis, extrativismo e populações tradicionais nas unidades de conservação de uso sustentável instituídas pela União; as políticas de assistência técnica e extensão rural para assentamentos rurais e reservas extrativistas; e, no caso de terras indígenas, a Política Nacional de Gestão Territorial e Ambiental de Terras Indígenas, no ano de 2012, são indicadores de que o momento pós-demarcatório tem obtido visibilidade na agenda de governo.

Vários estudos acadêmicos já abordaram a organização de setores populares da sociedade brasileira por reconhecimento e garantias fundiárias, a exemplo da interpretação dada à luta pela terra no Brasil estabelecida na Geografia Agrária por autores como Bernardo Mançano Fernandes (2005, 2008), de Oliveira (2001, 2005), Larissa Bombardi (2004), dentre outros, conformando a ideia de territorialização camponesa e de movimentos socioterritoriais. São justamente esses movimentos sociais organizados que estabeleceram, em grande medida, as possibilidades de uma nova "existência" socioespacial para diferentes grupos sociais do campo.

No caso indígena, organizações como o Conselho Indigenista Missionário, comissões pro-índio, dentre outras ONGs e associações locais, tiveram papel importante nas diversas mobilizações indígenas que 
conseguiram formular parâmetros mínimos e incidir sobre a forma de atuação do Estado brasileiro (MATOS, 1997; RAMOS, 1995, 1997; PACHECO DE OLIVEIRA, 2000; POZZOBON, 1999). Dentre as conquistas mais relevantes neste campo registra-se a garantia constitucional em relação à proteção aos modos de vida dos grupos étnicos, o que implica no respeito aos modos tradicionais de uso da terra e de apropriação dos recursos naturais, obrigando o Estado brasileiro a demarcar suas áreas por meio da oficialização e proteção de "terras indígenas".

No entanto, ocorrem situações em que a demarcação de uma terra indígena é uma resposta estatal a uma ação de retomada de território pelo grupo étnico, e também há casos de realocações. Nestes casos, as populações indígenas estiveram alijadas de seus territórios ancestrais ou tradicionais, ou usufruíam apenas de uma pequena parte dele.

Dentre esses movimentos territorialmente reivindicativos, nosso foco de atenção será direcionado àqueles que se edificam conjuntamente à construção ou reconstrução da identidade cultural e/ou étnica. Concordamos com Pacheco de Oliveira (2004) que no caso dos "índios do Nordeste", o desafio é ainda restabelecer os territórios indígenas, realizando a demarcação de suas terras, com a retirada de ocupantes não índios e, sobretudo, desnaturalizando a mistura como via única de sobrevivência e cidadania.

As questões e formulações que apresentamos aqui perpassaram a realização de uma pesquisa doutoral sobre os desafios contemporâneos do povo Xukuru do Ororubá, habitantes da região Agreste de Pernambuco, Brasil.

\section{Sobre territorialização}

Considerando a relevância que o antropólogo João Pacheco de Oliveira tem no campo da Antropologia Histórica, devido, especialmente, às suas pesquisas e orientações acadêmicas dedicadas a estudos sobre populações ameríndias, situação colonial e formação do Estado brasileiro, examinaremos com atenção as definições e o esquema analítico proposto pelo citado pesquisador para os conceitos de territorialização e reorganização social.

Suas proposições sobre territorialização partem de um argumento ou ideia base: a atribuição de uma base territorial fixa a uma sociedade se constitui enquanto ponto chave para a apreensão das mudanças pelas quais ela passa, afetando profundamente o funcionamento das suas instituições e a significação de suas manifestações culturais (PACHECO DE OLIVEIRA, 1998).

Apesar desta noção basilar servir a diferentes vertentes de interpretações, para o referido autor, serviria para refletir sobre a situação colonial e as relações com o Estado, de tal maneira sugerindo que: 
Se muitos fatores (internos e externos) podem ser indicados para explicar a passagem de uma sociedade segmentar à condição de sociedade centralizada, o elemento mais repetitivo e constante responsável por tal transformação é a sua incorporação dentro de uma situação colonial, sujeita, portanto, a um aparato político-administrativo que integra e representa um Estado (seja politicamente soberano ou somente com status colonial). O que importa reter dessa discussão [...] é que é um fato histórico - a presença colonial - que instaura uma nova relação da sociedade com o território, deflagrando transformações em múltiplos níveis de sua existência sociocultural (PACHECO DE OLIVEIRA, 1998, p. 54).

Na visão de Pacheco de Oliveira, a dimensão estratégica para se pensar a incorporação de populações etnicamente diferenciadas em um Estado-nação é a territorial, e por isso cunha ao termo territorialização ${ }^{5}$ uma versão particular, que lhe parece conveniente para explicar e analisar seu objeto de pesquisa:

Entiendo por territorialización todos los actos y saberes a través de los cuales un aparato de poder instituye una relación necesaria entre una población y cierto espacio geográfico, lo que implica en consecuencia un proceso general de reorganización social de aquella población, con la imposición de formas tecnológicas, padrones de uso de los recursos naturales, modos de ordenamiento político y símbolos identitarios. A pesar de tener su fundamento último en el uso (o amenaza de uso) de la fuerza, la territorialización implica también un movimiento paralelo por medio del cual los indígenas se apropian selectivamente de elementos exógenos y les atribuyen significados y funciones a veces muy distintos de los del discurso dominante (PACHECO DE OLIVEIRA,2006, p. 11).

Desta definição se compreende que a territorialização é um fenômeno que traduz um determinado conjunto de condições e concepções de mundo, estabelecido por um aparato de poder, e que configura as regras para as relações entre uma população e um determinado espaço geográfico. A cada novo processo de territorialização, esperam-se, como resultado, novos processos de reorganização social das populações afetadas e/ou protagonistas.

5. Segundo o autor: [...] "a noção de territorialização tem a mesma função heurística que a de situação colonial — trabalhada por Balandier (1951), reelaborada por Cardoso de Oliveira (1964), pelos africanistas franceses e, mais recentemente, por Stocking Jr. (1991) — da qual descende e é caudatária em termos teóricos" (PACHECO DE OLIVEIRA, 1998, p. 56). 
De cada processo de territorialização resulta um determinado cenário socioespacial, fruto de um conjunto de regras e condições. Entretanto, essa definição de territorialização não pretende esgotar o assunto, pois se constitui como um pano de fundo sobre o qual se evidenciam as ações e reações colocadas em curso. Nas palavras do autor, representa sua proposta de fio condutor da investigação antropológica:

[A territorialização] É uma intervenção da esfera política que associa - de forma prescritiva e insofismável - um conjunto de indivíduos e grupos a limites geográficos bem determinados. É esse ato político - constituidor de objetos étnicos através de mecanismos arbitrários e de arbitragem (no sentido de exteriores à população considerada e resultante das relações de força entre os diferentes grupos que integram o Estado) - que estou propondo tomar como fio condutor da investigação antropológica (PACHECO DE OLIVEIRA, 1998, p. 56).

Como expôs o autor em diferentes estudos (1998, 1999, 2004a, 2006, 2010), a expectativa é que a ideia de "situação", estabelecida por esses processos de territorialização, propicie interpretações mais circunstanciais e explicativas. Sugerindo, portanto, o estudo, em um determinado intervalo temporal, do vivenciado por uma determinada unidade sociocultural em virtude da sua rede e do seu contexto; e, sobretudo, em virtude das relações com o aparato de poder dominante.

Embora sugira a possibilidade de um uso mais amplo para a noção de situação (PACHECO DE OLIVEIRA, 1999), em virtude da derivação da noção de "situação colonial" formulada por Balandier (1951), suas propostas parecem estar especialmente calibradas para as circunstâncias de dominação advindas da colonização. E, a partir desse escopo, potencializa as possibilidades de pensar na política (diplomacia, interação, controle social, etc.) intrínseca à condição de dominação de um espaço, no qual existam territórios subordinados, onde estão grupos culturalmente ou etnicamente distintos.

Deste arranjo conceitual, merece destaque a sugestão do citado pesquisador de que pode haver diferentes repercussões para os distintos substratos humanos que compartilham um mesmo contexto de territorialização. Neste sentido, os povos indígenas criam estratégias de apropriação e reelaboração de significados e funções diferentes das impostas pelo aparato de poder dominante. Em outras palavras, a instituição de uma determinada relação "necessária", entre uma população e um determinado espaço geográfico, pode acontecer sob a égide de um poder dominante e, neste sentido, definirá muitos aspectos da vida societária Entretanto, os efeitos locais variarão conforme outros fatores.

Em trabalho publicado em 2010, Pacheco de Oliveira reforçou essa vertente: 
O processo de territorialização não exprime apenas as razões de Estado, mas nele se expressam também as concepções indígenas sobre tempo, pessoa e natureza do mundo. Tais concepções são atualizadas em um contexto social específico, no qual os significados e as estratégias podem referir-se a distintas escalas (por exemplo, intrafamiliar, intra-aldeia, no domínio étnico, no âmbito regional relacionado às agências externas, nas arenas nacionais e internacionais) e adquirir sentidos múltiplos. É nesse contexto que as instituições nativas e coloniais são contrastadas, gerando sobreposições e diferenças que configuram uma experiência singular, que pode ser objeto do olhar etnográfico (PACHECO DE OLIVEIRA, 2010, p. 31).

Em sua concepção, portanto, um processo de territorialização é algo complexo, incluindo não somente as razões de Estado - como o aparato de poder mais oficializado e robusto que se conhece - , mas também as expressões de outros segmentos sociais ou grupos étnicos que pensam diferentemente dos padrões estabelecidos pelo primeiro. Por isso o autor referiu-se às distintas escalas e múltiplos sentidos dessa repercussão. Tendo isso como pressuposto, é possível perceber os contrastes entre os quais as instituições nativas e coloniais se encontram, gerando configurações relacionais para determinado contexto espacial e caracterizando uma experiência singular, própria de seu tempo e das suas condições, conforme abaixo:

A noção de processo de territorialização dialoga e incorpora, assim, certas orientações críticas da teoria antropológica, absorvendo a preocupação com a criatividade dos sujeitos sociais e com a multiplicidade de planos em que as ações sociais podem ser lidas e inseridas. Os diálogos teóricos implícitos privilegiam, desse modo, o exercício do poder e os mecanismos de incorporação, os jogos de escala como constitutivos da sociabilidade e a análise da variação na cultura (PACHECO DE OLIVEIRA, 2010, p. 31).

Observando a sua obra seminal sobre a matéria, o artigo Uma etnologia dos 'índios misturados'? Situação colonial, territorialização e fluxos culturais, de 1998, e publicações subsequentes $(1999,2004 \mathrm{a}$, 2006, 2010), percebe-se que o autor, com o passar do tempo, realizou o esforço de aprimorar a definição do que concebia por territorialização. Devido aos limites de nosso texto, o conceito não será correlacionado ou comparado a definições de conceitos próximos, tais como território, territorialidade, desterritorialização, reterritorialização; no entanto, é necessário registrar que, ainda no campo da Antropologia, a noção de Pacheco de Oliveira guarda aspectos divergentes dos conceitos utilizados 
por outros autores (GUEDES, 2016; LITTLE, 1994, 2002; ALMEIDA, 2006, 2008, 2012).

\title{
Reorganização social
}

Como visto, segundo a concepção de Pacheco de Oliveira, cada situação (histórica, etnográfica, contextual) delimitada por processos de territorialização enseja novos processos de reorganização social das populações envolvidas. Embora o autor comente que ocorrem processos de territorialização com características distintas, ofereceu apenas um único quadro esquemático sobre a reorganização social consequente. Neste quadro, enumerou, do ponto de vista interpretativo, quais mecanismos são postos em marcha, ou melhor, quais diretrizes observar nesse fenômeno social que remodela os padrões sociotécnicos, o uso dos recursos naturais, o ordenamento sociopolítico e os símbolos identitários.

\begin{abstract}
Um processo de reorganização social que implica: (i) a criação de uma nova unidade sociocultural mediante o estabelecimento de uma identidade étnica diferenciadora; (ii) a constituição de mecanismos políticos especializados; (iii) a redefinição do controle social sobre os recursos ambientais; e (iv) a reelaboração da cultura e da relação com o passado (PACHECO DE OLIVEIRA, 2004, p. 22).
\end{abstract}

Segundo nosso ponto de vista, considerando a noção de territorialização defendida pelo autor, essas quatro implicações da reorganização social, apresentadas em texto de 2004a, são mais apropriadas para analisar o que denominava de movimentos paralelos. Isto é, para se examinar as reações e inovações que ocorreriam como respostas, entendidas como resistência ou permanência, das populações étnicas sob a imposição de uma territorialidade (colonial ou estatal) que não lhes era própria ou endógena.

Diferindo, portanto, substancialmente daqueles movimentos de reorganização social ocorridos intimamente associados às situações que impuseram apenas adequações para sobrevivência ou cooperação submissa, traduzindo em grande parte um lugar de inferioridade em um determinado sistema interétnico. Para esses casos, o autor apresentou argumentos ilustrativos e um panorama mais geral sobre as reorganizações ocorridas. No contexto dos momentos de territorialização vivenciados pelos povos indígenas no Brasil, expôs que:

Afastados de um destino coletivo, trilhando trajetórias individuais para escapar aos estigmas e para se fazer passar por brancos, os descendentes de indígenas tenderam a escamotear suas tradições culturais e abandonar sua língua, seja reduzindo o étnico à 
dimensão familiar e vivenciando um forte conflito entre esfera doméstica e esferas públicas, seja fragmentandoo ainda mais $e$, através de casamentos interétnicos, limitando-o à memória de alguns descendentes. O resultado desse processo foi sempre a invisibilidade da presença indígena dentro dos espaços da sociedade nacional (PACHECO DE OLIVEIRA, 2010, p. 34).

As reorganizações sociais de "adequação" - quando a territorialização via poder estatal exógeno ao grupo esteve fortemente estabelecida - devem ter sido numericamente superior em ocorrências, e a literatura etnográfica oferece inúmeros exemplos. No entanto, o autor não apresentou uma matriz tão didática para a compreensão do fenômeno. Provavelmente devido a retóricas e trajetórias na antropologia brasileira "preocupadas" com a extinção ou "aculturação" dos povos indígenas (RIBEIRO, 1970), lastreadas na tese de um inexorável destino de perda da cultura e da identidade indígena, como o próprio professor Pacheco denominou, uma "etnologia das perdas e das ausências culturais", como o próprio professor Pacheco denominou (PACHECO DE OLIVEIRA, 1998).

A matriz de Pacheco de Oliveira, portanto, se estabeleceu como fortaleza teórico-analítica para as situações nas quais, aparentemente, o caminho ocorre ao revés, isto é, da "mistura" e invisibilidade, como resultado da situação interétnica estabelecida, neste caso a "situação colonial" perene, para a diferenciação e fortalecimento da cultura e afirmação da identidade étnica.

Figura1 - Implicações inerentes ao processo de reorganização social.

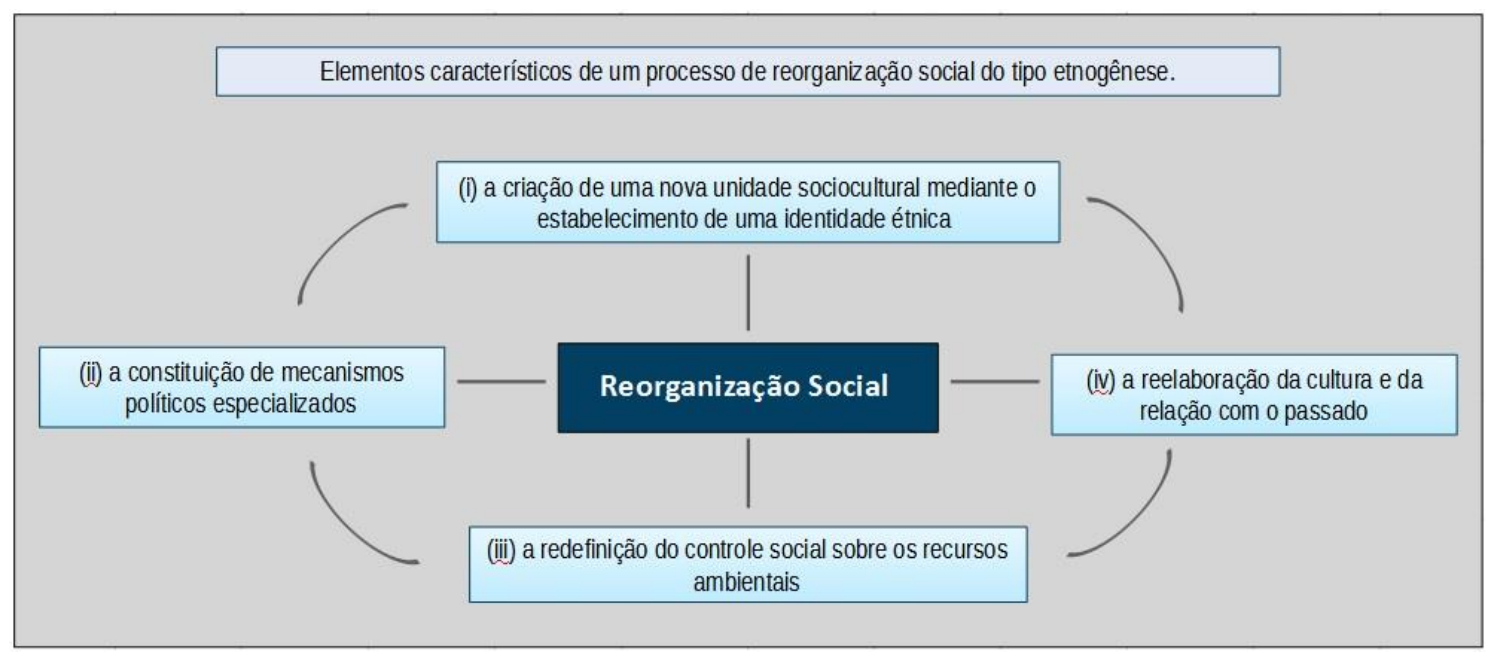

Fonte: elaboração própria a partir de OLIVEIRA, 2004a. 
Portanto, em consonância com esses argumentos, a nossa ideia foi adotar essa matriz como uma interpretação específica, a qual considera (e utiliza) as quatro implicações do esquema teórico como aspectos processuais próprios e inerentes aos chamados casos de etnogênese ou emergência étnica.

Deste modo, é possível adotar esta formulação como uma matriz que ordena o estudo do fenômeno da reorganização social quando atrelada ao fortalecimento, renascimento, ressurgimento ou mesmo gênese de grupos étnicos. De acordo com essa perspectiva, nestas situações, se espera encontrar ações que confluam em, pelo menos, quatro das direções citadas no esquema acima.

\section{O Nordeste indígena e a etnogênese}

O antropólogo João Pacheco de Oliveira também foi um dos grandes incentivadores para a formação do objeto de pesquisa e reflexão intitulado "índios do Nordeste", contribuindo para mudanças no panorama de interesse de estudiosos brasileiros em relação aos povos indígenas no Nordeste do país, que a partir da segunda metade do século XX cresceram em números populacionais e em visibilidade política.

Para o referido autor, os povos indígenas que atualmente habitam o Nordeste brasileiro (PACHECO DE OLIVEIRA, 2004a), assim como os demais povos indígenas no Brasil (PACHECO DE OLIVEIRA, 2010), provêm de culturas autóctones que foram envolvidas em processos de territorialização de distintas características. O primeiro, verificado da segunda metade do século XVI até as primeiras décadas do XVIII, corresponderia à "reunião" de distintos povos autóctones sob a tutela das missões católicas de catequese. Por meio deste processo, ficaram estabelecidas novas formas de trabalho, família, residência, sociabilidade e organização política.

Em seguida, com o retrocesso do monopólio religioso sobre populações indígenas e territórios, marcado pela expulsão dos jesuítas após a metade do século XVIII, e com o estabelecimento de uma nova organização estatal para tal finalidade, ambos promovidos pela política pombalina, iniciou-se um segundo processo de territorialização. Os índios estariam subordinados apenas às autoridades leigas e às regras de regularização da propriedade capitalista da terra. Neste novo processo de territorialização, a orientação diretiva era de caráter assimilacionista, incentivando os casamentos interétnicos e impondo o uso da língua portuguesa. Ademais, estava fortemente ancorado na viabilidade econômica do Brasil. Os indígenas seriam incorporados à sociedade nacional através de relações de clientelismo e de patronagem, sob a condição de agregados e dependentes dos proprietários formais das terras.

Um terceiro processo de territorialização pode ser sintetizado pela expressão "indigenismo tutelar", colocado efetivamente em curso na 
primeira metade do século XX. Estava voltado para a expansão das fronteiras econômicas e tinha por orientação a integração nacional, buscando acabar com a relativa autonomia e os padrões culturais contrastantes que ainda restavam no país (PACHECO DE OLIVEIRA, 2004a, 2010). Para isso, uma agência indigenista especializada oficial foi criada, com a prerrogativa de pacificaras relações locais entre indígenas e regionais e de regular o mercado de terras (PERES, 2004). Este terceiro processo de territorialização, um movimento iniciado nos anos 19701980, logra estabelecer novas formas de ação e prioridades, conjugandoas com as regras do regime tutelar e com o proceder da reserva de terras. Inspirados em referências organizacionais próximas da forma de atuação de entidades da sociedade civil e movimentos sociais no país à época, consegue realocar o protagonismo dos povos indígenas no cenário nacional.

Os apontamentos de Pacheco de Oliveira para pensar a reorganização social foram gerados a partir de um contexto acadêmico cuja marca foi o amadurecimento dos estudos e pesquisas versando sobre o "ressurgimento" de etnias consideradas extintas ou em processo de extinção. Frequentemente são citadas como marco inicial destes estudos, as contribuições do antropólogo Carlos Estevão de Oliveira sobre os "remanescentes indígenas" no Nordeste Brasileiro. Em 1937, ano das famosas palestras deste antropólogo, existia apenas um posto do Serviço de Proteção ao Índio na Região Nordeste. Foi criado em 1924, no município de Águas Belas, a partir de mobilizações do povo Fulniô, também conhecido por Carnijó. Os demais povos indígenas na região eram considerados extintos ou assimilados à população nacional pela historiografia e órgãos de governo. Naquele ano, Estevão relatava suas pesquisas sobre os Pankararu, da aldeia Brejo dos Padres, município de Tacaratu; citava a existência de mais outros três grupos; e sugeria que poderiam existir ainda outros (ARRUTI, 1997). Ocorreu que logo nas décadas seguintes, muitos grupos se mobilizaram pelo reconhecimento de sua identidade indígena, aos quais se somaram outros, em diferentes fluxos de mobilizações nas décadas de 1970 a 1990. Como destacou Pacheco de Oliveira (1998), na década de 1950, a relação de povos indígenas no Nordeste brasileiro incluía dez etnias; quarenta anos depois, em 1994, essa lista contabilizava vinte e três. Segundo os dados da sistematização mais recente disponível, publicada pelo Instituto Socioambiental (RICARDO; RICARDO, 2017), na região Nordeste (excluindo o estado do Maranhão) encontram-se atualmente trinta e nove etnias ${ }^{7}$.

Concordando com a perspectiva de Arruti (1997), as palestras de Carlos Estevão representaram um momento de inflexão sobre a história indígena no Nordeste, pois marcaram o início de um processo

7. São elas: Anacé, Atikum, Fulni-ô, Jenipapo-Kanindé, Jiripanco, Kaimbé, Kalankó, Kambiwá, Kantaruré, Kapinawá, Karapotó, Kariri, Kariri-Xokó, Karuazu, Kiriri, Pankararé, Pankararu, Pankaru, Pankará, Pankaiuká, Payayá, Pataxó, Pataxó Hã-Hã-Hãe, Pipipã, Pitaguary, Potiguara, Tabajara, Tapeba, Tapuia, Tingui Botó, Tremembé, Truká, Tumbalalá, Tupinambá, Tuxá, Xokó, Xukuru, Xukuru-Kariri, Wassu. 
relativamente rápido e, por que não, virtuoso de revitalização de tradições e de invenção socioculturais que transformou o Nordeste brasileiro em uma região etnograficamente relevante para os estudos da Etnologia no país.

É por isso que o fato social que nos últimos vinte anos vem se impondo como característico do lado indígena do Nordeste é o chamado processo de etnogênese, abrangendo tanto a emergência de novas identidades como a reinvenção de etnias já reconhecidas (PACHECO DE OLIVEIRA, 1998, p. 53).

Registra-se que processos parecidos, isto é, de etnogênese, ocorrem na contemporaneidade em estados de outras regiões do país, como ilustram os casos Kraho-Canela (MAURO, 2013) e Tapuio do Carretão (MOURA, 2008), dentre outros, mas também em outros locais do planeta. Na América Latina, por exemplo, temos diferentes casos na Argentina (GORDILHO; HIRSCH, 2010; LAZZARI, 2007, 2010; BIDASECA, 2010; LENTON, 2010). Por vezes, a etnogênese é interpretada apenas como um fenômeno recente, geralmente usado para designar o reaparecimento ou surgimento de grupos étnicos na atualidade. Todavia, Miguel Alberto Bartolomé (2006) sugeriu uma conceituação mais profunda, entendendo-a como um processo básico de configuração e estruturação da diversidade cultural humana. Segundo Bartolomé, as etnogêneses se referem ao dinamismo inerente aos grupos étnicos, cujas lógicas sociais revelam uma plasticidade e uma capacidade adaptativa que nem sempre foram reconhecidas pela análise antropológica, que muitas vezes esteve mais preocupada com a determinação de estruturas aparentemente coerentes nas culturas estudadas do que com a dinâmica inerente a todas as estruturas.

Considerando essa dimensão, a reorganização social, portanto, não seria um evento com datação de início e término definitivos, embora analiticamente seja utilizado este recurso para demarcar períodos, situações sociais ou configurações históricas. A reorganização social, portanto, estaria sempre em algum grau de atividade. Outro ponto fundamental para essa interpretação proposta é que ela foi promovida ativamente pelos interessados, em ações e reações, envolvendo tanto negociações e ações internas quanto a interação com o externo, incluindo aí o Estado, de acordo com os interesses contextuais.Um retroalimentando o outro.

\section{Redefinição do controle social sobre os recursos ambientais}

Dentre os quatro elementos característicos de um processo de reorganização social do tipo etnogênese que dialogam entre si, escolhemos a redefinição do controle social sobre os recursos ambientais como aspecto central a ser considerado na pesquisa de doutorado 
realizada junto ao povo Xukuru do Ororubá, nos municípios de Pesqueira e Poção, Pernambuco. Desde logo, nos pareceu que tal aspecto contribuiria significativamente para interpretar desafios da ordem da gestão ambiental e territorial, do modelo de agricultura desejado e do processo de recuperação da condição campesina das famílias Xukuru fatores elencados como problemáticas da citada pesquisa. Evidentemente, os demais aspectos da matriz podem ser encontrados neste caso etnográfico em estudo, assim como nos vários outros casos já estudados (ARRUTI, 2004; GRÜNEWALD, 2001, 2004; BARRETO FILHO, 2004), tornando a matriz uma sistematização bem ancorada em estudos para a região.

No que se refere ao controle social sobre os recursos ambientais, Pacheco de Oliveira não estabeleceu uma definição acurada para o termo. Por isso, buscamos explorar essa vertente com a intenção de favorecer a continuidade dessa possibilidade analítica. Inicialmente, ainda no esforço de atingir o objetivo do autor com a proposição, a expressão poderia sugerir algumas interpretações imediatas. A primeira e mais restrita equivale ao controle social sobre os recursos naturais dos ecossistemas; no entanto, a expressão também pode ser interpretada com maior amplitude, incluindo mais aspectos do contexto, no sentido material e simbólico, tornando-se equivalente a recursos circundantes, envolventes, incorporando, portanto, recursos dos ecossistemas naturais, além de toda materialidade produzida pelo povo ocupante.

Ao sugerir uma abordagem para a expressão que venha a contribuir com os diferentes fatores que são redefinidos no contexto da reorganização social de grupos étnicos, recorremos a alguns parâmetros teóricos clássicos, tais como o fato social de Durkheim (2007); a etnicidade de Barth (2000); e o controle cultural de Guilhermo Bonfil (1991), devido à contribuição que oferecem sobre a capacidade de decisão dos grupos étnicos a respeito dos bens culturais. Ademais, foi necessário recorrer à certa dose de empiria, como será apresentado em seguida.

\section{Exemplos brasileiros de redefinição}

As questões pulsantes no pós-demarcatório de terras indígenas, unidades de conservação de uso sustentável e terras quilombolas derivam em grande parte do estágio de apropriação que tais populações tiveram de seus territórios, antes da medida estatal de reconhecimento. No arcabouço teórico adotado aqui, remeteria ao tipo e grau do controle social sobre os recursos ambientais.

Portanto, conhecer esse passado é relevante; significa compreender a alienação das populações de seus territórios (ou a desterritorialização) e também as reorganizações sociais de caráter adaptativas ocorridas. Evidentemente, haverá diferenças gritantes nas questões em torno da gestão ambiental e territorial contemporânea entre as populações, 
conforme suas trajetórias (históricas) socioespaciais e suas condições recentes de apropriação de seus lugares tradicionais.

Isso pode ser melhor percebido, empiricamente, quando se observam etnias que tiveram parcelas com diferentes histórias de contato, com seus subgrupos tomando ao longo da história diferentes decisões geográficas, tais como os Yanomami, Kayapó e Miki/Manoki, dentre muitos outros. Nestas ocasiões, considerando isolamento e interação como chaves de interpretação, são expressivas as diferenciações nas formas e usos do espaço geográfico e dos recursos naturais, dentre outras variações.

Na perspectiva teórica adotada aqui, a interação significa "adaptarse" à territorialização estatal nacional, interagindo e "negociando" com seus aparatos de poder, cuja intencionalidade caracteriza-se pela imposição de formas tecnológicas, padrões de uso dos recursos naturais, modos de ordenamento político e símbolos identitários (OLIVEIRA, 2006).

Nesse processo de interação, que pode originar reorganizações sociais mais ou menos expressivas, há efeitos diversos, uma vez que os grupos vão estabelecer ações e reações específicas de manejo de bens culturais (sejam próprios ou alheios), ainda que percam poder de decisão em diferentes esferas. Conforme a contribuição de Bonfil Batalla (1991), a dinâmica cultural no contexto das relações interétnicas e, em especial, em situações assimétricas de cunho colonial, poderia ser organizada em poucos processos: imposição, supressão, alienação, resistência, apropriação e inovação.

Conforme a diferenciação que propomos ao arcabouço de Pacheco de Oliveira, quando a reorganização social está atrelada a movimentos identitários socioespaciais reivindicatórios, significará ganho de poder de decisão sobre bens culturais e naturais. Esta formulação pode ser percebida como verdadeira em diferentes exemplos brasileiros, sendo especialmente validada nos estudos sobre os povos e comunidades tradicionais.

Por exemplo, quando Diegues (2001) aborda as formas de apropriação comum dos espaços e recursos:

Os sistemas tradicionais de acesso a espaços e recursos de uso comum (comunitários) existentes no Brasil não são formas do passado, congeladas no tempo ou em total desorganização frente ao avanço da propriedade privada. Ainda que muitos desses sistemas tenham-se desestruturado frente a expansão capitalista, existem exemplos recentes que mostram a capacidade dos "comunitários" não só em reagir, mas também em reorganizar-se, recriando modos de vida e territórios de uso comum (2001, p. 97).

Segundo o autor, esses sistemas existem devido a um conjunto de regras e valores consuetudinários, através da "lei do respeito", em que uma teia de reciprocidades sociais, afirmando, em maior ou menor 
intensidade, o entendimento segundo o qual os recursos compartilhados devem ser usados com parcimônia, pois deles dependem a reprodução social e simbólica do grupo.

No Brasil existe um conjunto de experiências históricas que evidencia a capacidade das populações humanas de promover essa redefinição do controle social sobre os recursos ambientais e, com isso, satisfazer um número muito maior de pessoas - comparado ao status quo inicialmente vigente -, fazendo vigorar outras formas de relação entre humano e natureza.

Alguns casos se referem a experiências nas quais o declínio econômico de determinada atividade homogeneizadora do território fez com que os grandes proprietários e incorporadores fundiários se retirassem da região, chegando a, literalmente, abandonar as fazendas. Nestas situações, as populações remanescentes que viviam integradas ou marginalizadas ao sistema predominante continuaram a habitar as localidades, constituindo, a partir de então, outras configurações socioespaciais.

Segundo Diegues (2001), isso foi o que ocorreu no litoral sul do estado de São Paulo, ao final do ciclo econômico do arroz, onde uma parte da população passou a ocupar a região estuarino-lagunar de Iguape Cananéia com agricultura de subsistência e pesca, no século XIX. Esses habitantes tinham seu lugar de moradia mais ou menos fixo, e praticavam uma agricultura itinerante em "espaços comuns", onde não vigorava, na maioria dos casos, a "posse" ou a propriedade individual - sendo ainda de uso comum os mangues, os corpos d'água de lagunas e estuários, originando o que se passou a entender por população caiçara.

Outro exemplo, o município de Alcântara, no litoral ocidental maranhense, apresenta uma população preponderantemente rural e tem oficialmente reconhecido, em um mesmo perímetro e de forma contínua, um extenso território étnico, integrado por mais de uma centena e meia de povoados camponeses que reivindicam a condição de quilombolas e resistem às ameaças (recentes) relacionadas ao interesse do Estado no lançamento de artefatos espaciais. Os proprietários de fazendas de algodão e de engenhos de açúcar dos séculos XVIII e XIX, ao entrarem em derrocada econômica, abandonaram as terras, possibilitando o florescimento de um modo de vida particular, ancorado em regras costumeiras de relação com os recursos ambientais e entre grupos de parentes, vizinhos e compadres. Embora a historiografia regional enfatize o que entende como decadência de Alcântara e sua paralisia no tempo, indígenas desaldeados e escravos africanos passaram a viver livres da subordinação, construindo regras próprias para se assenhorear das terras e demais recursos após a retirada dos donos de engenho (SOUZA FILHO; ANDRADE, 2012; ALMEIDA, 2006).

É possível citar ainda outro caso emblemático: os seringueiros. Migrantes que chegaram à Amazônia em virtude do ciclo da borracha de 1879 a 1912, e encontraram condições de vida e trabalho bastante degradantes. Os patrões não permitiam que desviassem a atenção da 
extração do látex e, dessa forma, realizavam o aviamento de gêneros alimentícios e de todos os utensílios necessários, criando uma relação de extrema dependência. Após o declínio da exploração da borracha, devido à competição com países da Ásia, os grandes proprietários dos seringais abandonaram a região, deixando os trabalhadores em "suas terras". Essa população herdou as "colocações" - ou seja, os caminhos onde se encontravam as árvores produtoras - como lógica de distribuição entre as famílias, mas passou a utilizar outros recursos florestais, a cultivar o que antes era proibido e a explorar os recursos pesqueiros em termos de subsistência (DIEGUES, 2001; PORTO-GONÇALVES, 2005).

Importante notar que, nessas experiências brasileiras, a instituição de "novas" regras de uso do espaço e de apropriação dos recursos naturais ocorreu conjuntamente a constituição de identidades sociais. Isto é, um modo de vida, definindo também as fronteiras de pertencimento dos grupos. Neste sentido, e recordando a matriz apresentada por Pacheco de Oliveira (2004), a reorganização social promovida atua na redefinição do controle social dos recursos ambientais, mas incide também em outros eixos, como a reconstituição da identidade e da unidade sociocultural que estabelecem novas fronteiras de pertencimento.

Embora a síntese das experiências caiçara e quilombola citadas remeta à ideia da ocupação sociopolítica de um "vazio" (devido ao abandono das terras pelo desinteresse capitalista), existem inúmeros outros exemplos que tratam de redefinições ocorridas como resultado da reorganização social de populações frente às ameaças à reprodução de seus modos de vida, o que impulsionou a constituição dos movimentos sociais demandantes de regularização fundiária.

No caso dos seringueiros amazônicos, por exemplo, que eram invisíveis no cenário nacional nos anos de 1970, esses constituíram um movimento agrário no início dos anos de 1980 e, na década seguinte, conseguiram reconhecimento nacional, obtendo a implantação das primeiras reservas extrativas após o assassinato de Chico Mendes. Assim, em vinte anos, os camponeses da floresta passaram da invisibilidade à posição de paradigma de desenvolvimento sustentável com participação popular (BARBOSA DE ALMEIDA, 2004).

\section{O caso Xukuru do Ororubá}

O caso Xukuru do Ororubá também chama a atenção pela grande transformação ocorrida nas últimas décadas. Dee 1980, quando iniciam um forte movimento reivindicatório, à década de 2010, em que são impressionantes as transformações socioespaciais, alcançando altos graus de organização administrativa do seu território.

Naquele tempo (década de 1980), em termos fundiários, havia apenas 6,1 5 hectares de posse reconhecidamente indígena associados ao posto indígena localizado em São José, criado ainda na década de 1950. 
Fora isso, a população que ainda se encontrava no meio rural estava na condição de morador de fazendas ou posseiros em mínimas porções de terra na Serra do Urubá.

Segundo os cálculos e estimativas dos indígenas, corroborado por alguns estudos publicados (SOUZA, 1992; SOUZA et al., 2012; FERREIRA et al., 2011), as famílias Xukuru ocupavam pouco mais de $10 \%$ da área total delimitada no processo de identificação e demarcação da Terra Indígena Xukuru, estando o restante da área intrusada por aproximadamente 300 posses não indígenas.

A leitura de variados estudos sobre os Xukuru (HOHENTHAL JÚNIOR, 1954; BARBALHO, 1977; SOUZA, 1992; SILVA, 2008; entre outros) permite reconstruir desde tempos antigos, e com riqueza, o processo histórico de esbulho das terras Xukuru, não havendo divergências entre as referências bibliográficas consultadas sobre o fato de que o atual povo Xukuru do Ororubá possui ascendentes nos habitantes nativos da região que aparecem em textos do passado, com algumas pequenas diferenças gráficas - como Shucuru, Sucuru, Zucuru, Xacuru, Xicuru, Xucuru - , ocupando áreas dos atuais estados de Pernambuco e Paraíba, chegando até os limites com o Rio Grande do Norte. Não menos importante é o fato que o atual povo Xukuru do Ororubá também possui ascendência nos conhecidos por "Caboclos do Urubá" do século XX.

Portanto, para o caso específico dos Xukuru do Ororubá contemporâneos, habitantes da Serra do Urubá e cidades vizinhas, entendemos que há "um rastro" de pertencimento territorial bastante lógico que provém desde os períodos pré-coloniais. Admitindo, é claro, que ao longo deste percurso histórico houve diferentes instrumentos de territorialização do Estado nacional e repercussões socioespaciais, que provocaram a mistura dos Xukuru com outras populações nativas ${ }^{8}$, negras e brancas pobres, e também mudanças culturais significativas.

Finalmente, a Terra Indígena Xukuru é homologada com 27.555 hectares no ano de 2001 , situada no Agreste de Pernambuco, limitandose ao norte com o município de Poção e com o estado da Paraíba, ao sul com Mimoso, ao leste com Pesqueira e a oeste com Arcoverde; representando uma parte do território tradicional maior reivindicado ${ }^{9}$ como Xukuru.

Após muitas lutas, o povo Xukuru reconquistou o seu território, que foi reduzido pela FUNAI. Mas sabemos que temos índios Xukuru morando, vivendo nas cidades de Venturosa, Poção, Brejo da Madre de Deus, Belo Jardim, Sanharó, Alagoinha e nos povoados de Mimoso, Ipanema e Aldeia Velha, que ficaram fora da demarcação do

8 Notadamente, sabe-se dos Paratió, grupo nativo que, pelos registros, também ocupava a região e foi aldeado na mesma missão católica que os Xukuru (BARBALHO, 1977; SILVA, 2008).

9 Segundo a tradição oral do grupo, o território tradicional seria, segundo termos atuais, no sentido lesteoeste, do Brejo da Madre de Deus (PE), nas proximidades de Arcoverde (PE), e no sentido norte-sul, da região limítrofe aos estados da Paraíba e Pernambuco, até a Pedra Serrana, no município de Pedra (PE) (FERREIRA et al., 2011). 
território. Com isso a gente deixa claro que têm indígenas vivendo fora do território, mas não deixam de ser índios ${ }^{10}$.

Portanto, o grupo sai de uma condição de subordinação agrária, em que eram empregados, diaristas, arrendatários ou minifundários em suas próprias terras imemoriais, para uma nova configuração onde 27.555 hectares são reconhecidos como terra de uso tradicional conforme legislação vigente, devendo ser de uso exclusivo da etnia conforme seus usos, costumes e tradição.

Em termos demográficos, também há um incremento significativo. Com as garantias constitucionais de 1988 para o reconhecimento dos direitos indígenas, a mobilização política liderada pelo cacique Xicão Xukuru e o pajé Zequinha, e os avanços no processo de demarcação fundiária, as famílias dispersas em diferentes lugares do país ${ }^{11}$ puderam se reagrupar, e as que estavam na região puderam assumir a identidade indígena.

Recuperando informações do Serviço de Proteção aos Índios, o professor Geraldo Lapenda, catedrático de língua, na publicação de 1962 sobre "O Dialeto Xucuru", informava uma população aproximada de 2.200 caboclos (LAPENDA, 1962).

Souza (1992), com base no levantamento do Posto Indígena da Funai de 1989, informa que o grupo contava com uma população aproximada de 3.254 habitantes, excluindo aqueles que estavam nas cidades.

Teixeira e Costa (2013), ao debater os números demográficos dessa etnia, apresentam uma estimativa autoral de 6.000 pessoas no ano de 2000 na Terra Indígena Xukuru. Enquanto isto, os números do IBGE indicavam 1.403 pessoas em 2000 em toda a área rural da cidade de Pesqueira, e em 2010 indicam uma população de 7.672 pessoas somente para a Terra Indígena Xukuru. Em suas conclusões, expõem que:

De fato, o número de autodeclarados indígenas na zona rural do município de Pesqueira mais que triplicou entre 2000 - próximo ao ano da homologação da TI Xukuru e 2010. O fenômeno deveu-se, muito provavelmente, ao advento de novos contornos na ordenação social e econômica na terra indígena e no consequente processo de autorreconhecimento identitário (TEIXEIRA; COSTA, 2012, p. 4).

\footnotetext{
${ }^{10}$ Texto atribuído aos participantes Xukuru da oficina de mapeamento do projeto Nova Cartografia Social dos Povos e Comunidades Tradicionais do Brasil, fascículo Xukuru do Ororubá - PE (SOUZA et al., 2012, p. 4).

11 Para aprofundamento sobre os movimentos migratórios da população indígena da Serra do Urubá, ver obras de Edmundo Monte (2010, 2012).
} 
As estimativas mais atuais da organização sociopolítica Xukuru, que leva em consideração dados da equipe de saúde indígena, chega ao número de 11.000 pessoas.

Além disso, há uma estrutura pública para as políticas de saúde e educação diferenciadas voltadas a atender as especificidades da população indígena. Em termos de estrutura educacional, atualmente, os Xukuru dispõem de um corpo docente de aproximadamente 200 professores, distribuídos em 42 escolas localizadas nas 24 aldeias do território indígena. Para os serviços médicos, os Xukuru contam com o auxílio de equipes formadas por três médicos, três enfermeiros, doze auxiliares de enfermagem, três auxiliares de consultório dentário, vinte agentes indígenas de saneamento (AISAN) e 24 agentes indígenas de saúde (AIS); em termos de estrutura física há um polo base, cinco postos e cinco consultórios odontológicos para uso.

Para administrar esse novo território e garantir o acesso às políticas públicas, o povo Xukuru desenvolveu e aperfeiçoou uma estrutura sociopolítica interna composta por instâncias de saúde, educação, lideranças, juventude e agricultura, além de uma associação e de uma assembleia anual.

\section{A reorganização em andamento}

Tem muito parente iludido, tem camarada que ficou com aquela mania do fazendeiro. O fazendeiro foi embora. Que tinha aquela história de dizer, ouvia lá na Cana Brava mesmo, algum parente dizer: se esses fazendeiro for embora, nós vamo morrer tudo de fome! Mas até agora, eu não vi um índio na Cana Brava morrer de fome, nenhum! Nós num morreu de fome não e o fazendeiro foi quem se danou-se pra lá... ${ }^{12}$

Em um desabafo durante a plenária de uma assembleia do povo Xukuru do Ororubá, a liderança indígena da Aldeia Cana Brava, rememorando algumas afirmações dos períodos de mobilização pela demarcação, recordou que alguns parentes duvidavam da capacidade de subsistência alimentar e econômica das famílias caso as terras retornassem para o controle indígena. Como em muitos outros lugares do país, havia a ideia disseminada na sociedade envolvente sobre a incapacidade dos índios de estabelecerem terras produtivas do ponto de vista agropecuário, e também dúvidas quanto à capacidade de sobrevivência das famílias sem a estrutura e apoio dos ocupantes nãoíndios. A novidade trazida no trecho citado, no entanto, é a noção de que essa dúvida também pairava na cabeça de alguns Xukuru do Ororubá.

12 Fala em plenária do sr. Cecílio, da Aldeia Cana Brava, na Assembleia Xukuru do Ororubá realizada na Aldeia Capim de Planta no ano de 2012. 
Na pesquisa sobre o processo de organização política e elaboração simbólica do povo indígena Xukuru do Ororubá, Kelly Oliveira (2006), também se deparou com o mesmo em suas entrevistas. Na entrevista realizada em 2005, João Batista habitando na Aldeia Jitó, afirmou:

Eu fui criado e me entendi de gente trabalhando ao fazendeiro. Aí nós fomos tocando a vida. Nós tínhamos medo, assim... o pessoal dizia que as terras vai sair, o Governo vai indenizar, os fazendeiros vão embora e vai ser entregue". E a gente dizia: "Eita, a gente vai morrer de fome. Vai morrer de fome porque a gente vive lutando, trabalhando com o fazendeiro. Tirava conta, trabalhava na diária arrancando toco, brocando mato.

Em coerência com a linha de pesquisa proposta naquela ocasião, a citada autora analisou a situação, correlacionando-a com os medos de assumir a identidade Xukuru e as dificuldades para a integração política interna do grupo. Além do medo da reação violenta dos não índios que tinham propriedades na área, havia uma grande barreira a transpor: muitos foram submetidos a uma vida inteira de trabalho para os nãoíndios, de maneira que desconfiavam ou não acreditavam na proposta de se tornarem donos do território. Em seguida, a autora esboçou isso como um conflito interno, provocado por essa antiga relação com o patrão. Se por um lado supria as necessidades de trabalho e sustento, por outro também era o agente motor da situação de opressão em que os índios viviam. Enquanto alguns se mobilizavam pela demarcação das terras, outros temiam a fome e o desemprego (OLIVEIRA, 2006).

Durante aquele período, se propagandeava na cidade de Pesqueira que, devido à retirada dos fazendeiros da área, ocorreria drástica redução na produção de alimentos, baixando a oferta no comércio local, gerando problemas de abastecimento e uma crise econômica ${ }^{13}$. Tal enunciado posteriormente não se comprovou. Contrariando as especulações, uma produção bastante diversificada de frutíferas, oleícolas, mandioca, milho e feijão, associada à criação de pequenos animais, oriunda da Serra do Urubá, serve atualmente a indígenas e aos moradores e às escolas de Pesqueira.

Observa-se, pois, uma nítida contraposição aos resultados do modelo convencional anterior implementado na Serra do Urubá, baseado na hegemonia das fazendas de gado e no monocultivo de áreas irrigadas de milho doce e tomate para as indústrias agroalimentares (ARAUJO; ORDONIO, 201 1), quando a fome já era um dado da realidade.

Para a compreensão deste quadro anterior de fome e desnutrição na localidade, é possível recorrer à pesquisa de Edson Silva (2008), que reconstruiu esse cenário a partir da correlação entre os relatos dos

13 Evidentemente, o enunciado parte de uma perspectiva anti-indígena, servindo à campanha contra o reconhecimento dos direitos fundiários dos indígenas habitantes do local. Está atrelado a antigos (e ainda presentes) preconceitos consolidados na imagem sobre os índios no Brasil. 
indígenas entrevistados sobre a posse, uso da terra e condições de vida dos seus antepassados, bem como através de documentos oficiais e notícias de época. Este esforço historiográfico reconstituiu as principais transformações na Serra do Urubá: do final do século XIX ao início do século XX, quando esteve dominada pelos grandes criadores de gado, e, nas áreas úmidas, por engenhos de cana produtores de rapadura, com mão de obra indígena; e do período posterior, a partir dos anos 1950, com a instalação da produção industrial de doces e conservas em Pesqueira, registrando a alarmante pobreza, fome, mendicância, mortalidade e desnutrição infantil na Serra e nas periferias urbanas do município, à margem do louvado progresso industrial, principalmente durante as secas periódicas na região (SILVA, 2008).

Como escrevera um prestigiado religioso à época - e aparece registrado em artigos de jornal local (década de 1950) -, a situação era de alta do custo de vida, fome e miséria generalizada em Pesqueira. Uma lógica econômica baseada na criação de gado ou na agroindústria substituíra a produção de alimentos, expulsara a maioria de seus produtores, isto é, os pequenos agricultores - os índios moradores na Serra do Urubá. Um número considerável deles foi forçado a abandonar seus antigos locais de moradia e se concentrar na periferia da cidade. Outros passaram à condição de mão de obra para as fábricas, como fornecedores de matéria-prima, ou como operários (SILVA, 2008).

Retomando a fala inicial desta sessão, ainda que o processo de redefinição Xukuru do Ororubá continue em curso, a fala da liderança da Aldeia Cana Brava durante a plenária de 2012 reforça que a saída ou retirada dos fazendeiros, como ação de ruptura no bojo desse processo, não trouxe a fome.Pelo contrário, à similitude das outras experiências históricas brasileiras citadas em tópico anterior, reverteu a desigualdade no acesso aos bens naturais e, junto a outras ações, possibilitou alterar o quadro anterior, bem documentado, de fome no local.

\section{O pós-demarcatório}

Após o reconhecimento oficial (estatal) das terras tradicionais - em suas diferentes figuras jurídicas, tais como reservas de desenvolvimento sustentável, reservas extrativistas, áreas quilombolas ou terras indígenas -, novos arranjos socioespaciais se estabelecem sobre aquele delimitado espaço geográfico. Por mais que, em tese, várias destas unidades sejam criadas para legitimar um uso tradicional já em curso por determinada população, é evidente que a instituição legal dos limites dessas áreas gera maior proteção e autonomia para que a população beneficiária coloque em curso seu modo de vida. Estes, em muitas ocasiões, se encontravam seriamente ameaçados até a medida administrativa legal ser tomada. Em algumas situações, como no caso dos Xukuru do Ororubá, a população já havia perdido quase completamente a posse ou o uso autônomo das terras. 
Assim, a regularização de uma parcela do território nacional em benefício de determinada população, reconhecendo (em parte) seus direitos de autorregular-se, passou a ser um "divisor de águas". Essa condição em particular, efetivada ou em via de efetivação, provoca profundas mudanças na vida dessas populações. Essa repercussão socioespacial, que pode ser considerada um tipo de reterritorialização (LITTLE, 1994; GARLET; ASSIS, 2009; HAESBAERT, 2004; SOUZA, 2007), na concepção de Pacheco de Oliveira, pode ser entendida como uma forma específica de territorialização, na qual importa ao Estado delimitar os limites físicos espaciais e de autonomia para determinados grupos sociais e étnicos. Assim, contraditoriamente, o proceder das reservas de terras possibilita a expansão das fronteiras econômicas e a utilização de "todo o resto" (o que não está reservado) para a expansão desenvolvimentista do Estado.

É importante mencionar, por outro lado, que as "demarcações de terra", que garantem alguma segurança jurídica para povos indígenas, comunidades afrodescendentes e outras categorias sociais, ainda estão longe de contemplar a totalidade das demandas desses povos e comunidades tradicionais. No Brasil, ainda existem inúmeras dessas populações carecendo de qualquer garantia fundiária oficial sobre as suas terras de uso tradicional ou ancestral.

Do ponto de vista dos povos indígenas e comunidades tradicionais, as angariadas vitórias decorrentes das mobilizações por reconhecimento à diferença e pelo acesso à terra, o resultado esperado é que, pelo menos, parte do território tradicional reivindicado seja homologado, trazendo garantias fundiárias. Assim, quando se encontram nessa etapa posterior ao reconhecimento oficial, inicia-se um novo desafio: traduzir socioespacialmente a (re)organização, o que resulta em novas questões e demandas. Do ponto de vista do Estado, com a resolução da questão fundiária, cessam-se os conflitos mais violentos. Por outro lado, inicia-se o desafio de oferecer medidas oficiais de assistência, proteção e monitoramento, que deverão ser colocadas em prática.

Para a população beneficiada também se abrem novos desafios. As próprias lideranças Xukuru passam a denominar esta fase de "segundo momento da luta Xukuru", ou seja, as lutas do momento posterior à demarcação.

Portanto, o pós-demarcatório é o marco de um novo tempo para o grupo étnico reivindicante, pois resulta de uma luta pela terra, em parte, vitoriosa. Por conseguinte, no seio dessa sociedade, as maiores preocupações e mobilizações vão mudando de foco. De temáticas e atenção prioritária a fatores fundiários, ao reconhecimento oficial, ainda muito atreladas à tensão com agentes ou setores não indígenas, vão passando pouco a pouco para outras temáticas relevantes, referentes à administração do território e do grupo, além de voltarem-se mais fortemente para o acesso às políticas públicas, sejam aquelas de caráter universal, sejam aquelas destinadas especificamente aos povos indígenas. 
É necessário chamar atenção para o fato de que no Brasil, o processo de regularização fundiária das terras indígenas com a finalidade da conservação cultural, além de um advento historicamente tardio, tem sido um processo administrativo muito demorado. Isto resulta que, até que a garantia territorial fosse oficialmente estabelecida, grande parte das etnias estava sob sérias ameaças de sobrevivência física e cultural. Outro ponto preocupante é que há casos nos quais, quando se alcançam as garantias jurídicas e efetivas, as condições agrárias e ecológicas do local já estão bastante alteradas. Portanto, modelos e regras ancestrais do grupo, que conformavam seus sistemas socioecológicos, podem não mais se encaixar adequadamente às características ecológicas vigentes naquele espaço físico reservado. A intensidade e os tipos de interação com a sociedade hegemônica também estabelecem necessidades específicas. Em alguns outros casos, as próprias organização e estrutura social do grupo, que estabeleciam a forma de gerir e situar-se no território, também podem ter sido drasticamente afetadas.

Então, pode ser tentador seguir uma linha de raciocínio do ponto de vista das perdas, ou seja, pesquisar como essas sociedades eram ou deixaram de ser. Retomando, como Pacheco de Oliveira (2004) denomina, uma "etnologia das perdas" na perspectiva da busca por vestígios, uma espécie de ciência errática ou de registro salvaguardista de determinado grupo ou organização social antes de sua "extinção", "integração" ou "aculturação". No entanto, e justo ao contrário, a experiência Xukuru do Ororubá, assim como a de outros povos indígenas do Nordeste, se mostra extremamente rica para uma análise científica que privilegie a inovação e a produção de cultura e, sobretudo, como um determinado grupo efetivamente (não sem contradições) estabelece e administra o "novo".

Portanto, para se avançar em aspectos para além da questão fundiária, passam a ser bastante úteis estudos que levem em consideração a qualidade dinâmica das culturas indígenas e também o papel dos grupos étnicos como definidores e redefinidores de diferentes tipos de fronteiras. Neste sentido, temas ou conceitos como controle social, tomada de decisões, apropriação e elaboração cultural, inovações políticas, criações institucionais e organizativas ganham fundamental importância. E tratando-se dos desafios relacionados à gestão dos recursos naturais, as questões da agrobiodiversidade, da autonomia, da recampesinização, da transmissão de conhecimento e das formas de ação social coletiva também ganham destaque.

Como síntese, é possível afirmar que o contexto posterior à demarcação é um conjunto de circunstâncias (legais e práticas) que permitem aos povos indígenas estabelecer reconstruções e redefinições (em novos conflitos) de normas culturais ou de projetos ideológicos de gestão da vida comunitária e do território, para se adequarem a novas condições contemporâneas.

No caso Xukuru do Ororubá, é possível afirmar que os seus "desafios contemporâneos" correspondem ao momento pósdemarcatório. É uma fase que se inaugura em princípio dos anos 2000 , 
mas que, evidentemente, não se refere especificamente a datas precisas, mas sim a toda uma conjuntura de mudanças.

É conveniente mencionar resumidamente alguns marcos do início deste período. O assassinato da grande liderança, cacique Xicão Xukuru, aconteceu em 1998, e até o ano de 2003 outras mortes ocorreram em reação violenta à organização e luta pela terra dos Xukuru. No ano 2000, o novo cacique geral é revelado e oficializado por meio do sistema político-religioso xukuru: Marcos Araújo, com dezessete anos na época. Em 2001, a demarcação das terras reivindicadas foi finalmente homologada pelo Estado brasileiro. Durante todo este período ocorrem ações de retomada de terras realizadas pelos Xukuru para acelerar a saída dos ocupantes não índios e os procedimentos do governo federal ${ }^{14}$.

Após avanços consideráveis no acesso e implementação dos sistemas de saúde e educação no território, no ano de 2004 se dá um marco muito relevante para a gestão e sustentabilidade no território. A IV Assembleia Geral do Povo Xukuru do Ororubá é realizada na Aldeia São José com mais de 500 participantes representando todas as aldeias do território, e nela se debate o tema "Pensando o Desenvolvimento do Nosso Povo a partir do Cuidado com a Mãe Natureza". Na carta final do evento, declaram:

Dessa forma, com a reconquista do nosso território, a custa de muita luta, perseguições e mortes de nossas lideranças, reafirmamos o nosso desejo de romper com o modelo de produção e exploração das terras que nos foi deixado (Carta da IV Assembleia Geral do Povo Xukuru do Ororubá, 2004).

Em 2005, começa o primeiro projeto de assistência técnica e extensão rural (ATER) no território Xukuru através de uma entidade não governamental colaboradora, que logra acessar recursos do Ministério do Desenvolvimento Agrário.

É possível dizer que, a partir destes últimos dois marcos, os Xukuru encontram-se plenamente na fase comentada anteriormente, que perdura até os dias de hoje.

O povo Xukuru do Ororubá ainda não possui um plano de gestão ${ }^{15}$ estrito senso, isto é, um documento firmado com este propósito. No entanto, possui um conjunto de bens culturais próprios que caracteriza um funcionamento global de preceitos, mecanismos e instâncias de decisão, dando forma a um tipo específico de controle cultural (BONFIL BATALLA, 1991), caracterizando (não sem inconsistências ou contradições) uma forma de ver e atuar sobre os desafios do contexto pós-demarcatório. Neste quesito, destacam-se a sua organização

14 A desintrusão de ocupantes não índios demanda o reassentamento de pequenos posseiros e a indenização das benfeitorias dos grandes fazendeiros.

15 Os planos de gestão têm sido uma ferramenta que tem ganhado cada vez mais adeptos entre os povos indígenas no Brasil, e vai adquirir contornos e finalidades peculiares em cada localidade. Eles não são documentos que encerram em si as soluções, mas são vistos como uma das possibilidades de se mediar diálogos internos e com o externo. Devem ser reelaborados de acordo com as mudanças que ocorrem. 
sociopolítica contemporânea, de expressiva capilaridade, com suas instâncias administrativas, eventos periódicos de mobilização, assembleias, elaboração de cartas de intenção e as regras e noções de uso do território que foram sendo estabelecidas e aperfeiçoadas, desde a mobilização pela reocupação do território na década de 1980 até os dias de hoje.

\section{A proposição de uma abordagem}

Analisadas sob uma perspectiva diacrônica e panorâmica, essas drásticas transformações socioespaciais de retomada de lugares e reconhecimento de identidades étnicas ou culturais podem ser vistas sob diferentes perspectivas analíticas. Diferentes marcos teórico-conceituais poderiam ser selecionados para analisar essas mudanças, uma vez que podem ser interpretadas como transição entre diferentes "situações sociais" (GLUCKMAN, 2009) ou como conversão de diferentes "territorialidades" (HAESBART, 2004). E até mesmo poderiam ser observadas a partir da perspectiva da transformação na relação de "sistema de objetos, sistema de ações" (SANTOS, 2006). Embora tais marcos tenham sido gerados a partir de diferentes referências ou escolas de pensamento, entendo que podem ser acionados para representar e analisar as mudanças ocorridas em todos os exemplos citados, bem como no caso Xukuru do Ororubá, compondo adequados arcabouços teóricos para os estudos de apoio à gestão ambiental e territorial.

Neste ensaio, considerando referências teóricas e aspectos empíricos, privilegiamos a análise sobre o desafio da reorganização social, partindo da matriz de Pacheco de Oliveira, propondo, à guisa de conclusão, o construto teórico da "redefinição do controle social sobre os recursos naturais e bens culturais". Por construto teórico, entendam-se abstrações, modelos ou conceitos em processo de elaboração. Os construtos teóricos normalmente se justificam quando são elaborados a partir de fenômenos ou constatações difíceis de serem compreendidos pelo atual estado da arte das reflexões acadêmicas, bem como, conforme apresentamos, quando propõe uma formulação que integra diferentes teorias ou se trata de uma formulação que dá seguimento ainda não explorado por alguma teoria original. O construto não deixa de ser um conceito, porém agregando significações adicionais ao que foi "inventado" ou "adotado intencionalmente" com um propósito definido. É uma forma de se buscar maior precisão ao que se está pesquisando ou formulando, a fim de que seja integralmente compreendido pelos leitores. A finalidade é que não sejam interpretados como conceitos ou marcos teóricos totalmente acabados, tampouco deixem de fazer referência às teorias ou concepções das quais foram originados.

Esse construto teórico foi formulado inicialmente a partir do conhecimento acumulado e do cruzamento de algumas referências bibliográficas Entretanto, não deve ser interpretado como um exercício 
exclusivamente teórico, pois, no caso, seria contrariar o método de análise escolhido que buscou observar dados de realidade, seja da análise dos nossos dados de campo, seja de outros estudos de caso documentados. Evidentemente, é possível alcançar a mesma premissa destacada pelo construto por meio de outros referenciais teóricos, conhecidos na Ecologia política, na Antropologia e na Geografia, não mencionados ou utilizados nesse texto. Uma vez que não se trata de uma formulação por si polêmica, esperamos que seja compreendido como a síntese de uma abordagem necessária.

Tendo exposto esses entendimentos preliminares, apresentamos alguns aspectos centrais e concisos a respeito da redefinição do controle social sobre os recursos naturais e bens culturais. É possível entender que essa operação dialoga com os estudos sobre conflitos socioambientais, mas tem viés próprio. Da maneira como está sendo proposta, deve ser entendida como uma operação que, do ponto de vista dos seus promotores, objetiva à resolução de conflitos ou o estabelecimento de uma nova configuração na qual se modifiquem as condições de acesso e distribuição (desigualdade, restrições, privilégios, etc.) aos recursos ambientais - entendidos como a soma dos recursos naturais e bens culturais.

Vale mencionar que essa "resolução" será sempre temporária, admitindo, por princípio, que qualquer sociedade estabelece para ela e seu ambiente um equilíbrio precário (BIRNBAUM, 1995). Além disto, essa "resolução" não é livre de contradições nas medidas tomadas ou na nova conjuntura instaurada. A redefinição do controle social sobre os recursos ambientais é levada a cabo através de diferentes tipos de experiências, apresenta temporalidades nem sempre fáceis de serem delimitadas, mas, necessariamente, significa rupturas com partes ou o todo vigente. Essas redefinições do controle social são iniciativas no bojo dos processos de reorganização social que tratam de implementar novas formas e configurações socioespaciais, requerendo atualizações, adaptações, inovações e negociações de âmbito interno e externo de cada unidade sociocultural.

Defendemos que estudar e sistematizar como se processou e como se processa a redefinição do controle social sobre os recursos naturais e bens culturais pode ser uma abordagem extremamente útil e complementar às construções de planos de gestão ambiental e territorial.

Comumente, as construções sociais por trás dos planos atuais de gestão ambiental e territorial vêm consolidar (ou mesmo oficializar) coletivamente regras de uso e manejo já tradicionalmente adotadas e que, por diferentes motivos, encontram-se ameaçadas ou em declínio. No entanto, como apontam algumas experiências em curso, também servem para atualização de normas sociais ou estratégias políticas frente a novas conjunturas.

Vejamos o ponto de vista do professor e coordenador indígena da Associação Wyty-Cate dos Povos Timbira do Maranhão e Tocantins, Jonas Pyn Heh Gavião, expresso na abertura da publicação que sistematizou o 
plano de gestão territorial e ambiental de seis das oito terras indígenas timbira demarcadas pelo Estado brasileiro:

Há alguns anos, os mehin (autodenominação dos povos Timbira) começaram a perceber que, com as mudanças que estavam acontecendo nas terras indígenas demarcadas pelo Governo, era necessário realizar grandes reuniões de kà (pátio), com os outros krin (aldeia), para planejar o futuro do povo como um todo. Essas grandes reuniões, juntando todos os pahi (chefe de aldeia), sempre tinham uma pergunta central: como vamos continuar vivendo bem, em um pje (terra) que agora tem limites, com o surgimento de novas aldeias, o nascimento de crianças e o cupen (branco não-indígena) chegando mais perto e de um jeito diferente, com máquinas e grandes projetos que o governo acha bom construir perto de nossas terras? Como vamos continuar fazendo festas, se alimentando, falando a nossa língua e protegendo os limites de nossas terras das invasões dos cupen? (Associação Wyty-Cate, 2012, p. 4-5).

Esta fala é emblemática para ilustrar quais tipos de preocupação conformam o cenário pós-demarcatório a que estamos nos referindo. Inclusive, nos recorda que é importante mencionar que o Estado peca não somente pela ausência de ações de apoio, mas também pelas opções tomadas em termos de desenvolvimento econômico e que afetam os povos indígenas em seus direitos. As máquinas e grandes projetos a que se refere o professor gavião são hidrelétricas, linhas de transmissão de energia, estradas, mineração e projetos agropecuários.

Nessa passagem também fica claro que, diante da percepção dos próprios povos timbira sobre o contexto de mudanças e ameaças sobre os seus territórios demarcados, houve a necessidade de se estabelecer novos mecanismos políticos especializados para enfrentar a situação. Evidentemente, a constituição desses mecanismos deriva de um modo de ser específico em diálogo com as ferramentas de mobilização e luta contemporâneas. As grandes reuniões de pátio, juntando aldeias de outras terras indígenas do povo Timbira para se planejar, derivam de um mote ancestral. Em outro trecho do mesmo documento, o professor Pyn Heh explica que:

Desde os tempos antigos os Timbira se reúnem duas vezes por dia, de manhã cedo e no fim de tarde, no pátio de suas aldeias, para planejar suas atividades e conversar sobre os encaminhamentos necessários para o bom funcionamento do krin. Nessas reuniões diárias no kà, os mehin decidem quais as coisas importantes que devem ser feitas para manter o movimento da aldeia. Para eles o krin deve estar alegre, com todos desenvolvendo suas atividades no rumo do mehin. 
Alguns homens vão caçar, outros vão para cidade cuidar das coisas do cupen, conversar com prefeito, levar os aposentados para receber salários, fazer compras, algumas mulheres vão pra roça ou vão pro mato catar fruta. Todos na comunidade, após a reunião do pátio, sabem o que vai acontecer naquele dia. Esse é o movimento, o plano do mehin (Associação Wyty-Cate, 2012, p. 4).

Diante da nova realidade dentro e no entorno das terras indígenas timbira, os povos Krahô, Apinajé, Krikati, Gavião Pykbojê, Canela Apanjekrá e Canela Ramkokamekrá têm tentado construir uma unidade pan-Timbira para a gestão integrada e fortalecimento mútuo.

Nessa publicação que sistematiza o plano de gestão, há informações que caracterizam o contexto que impõe esses novos desafios e também sugestões de caminhos, construídos através de diagnósticos socioambientais, oficinas técnicas, assembleias, reuniões comunitárias, etnomapeamentos e formação de pesquisadores indígenas, para alcançar soluções. Segundo o que relatam, desde o início da década de 1990 os Timbira vêm discutindo estratégias para o enfrentamento dos desafios impostos pelo contato com a sociedade nacional e o confinamento territorial; trata-se do crescimento populacional dentro e no entorno de suas terras, dos impactos socioambientais decorrentes da implantação de projetos de infraestrutura, do avanço da fronteira agrícola na região que habitam e do surgimento de novas necessidades de bens e serviços (Associação Wyty-Cate, 2012).

O bem-estar Timbira está intimamente associado à conservação do seu bioma, o Cerrado. Jonas Pyn Heh Gavião estabelece claramente esta relação:

Como vamos segurar o jeito de ser mehin? Pra segurar o jeito de ser mehin, temos que segurar o Cerrado. Ele é a nossa casa. Nossas histórias, mitos, cantorias, o conhecimento das plantas, raízes, frutos e bichos, todo o nosso jeito de viver e ver o mundo faz parte do Cerrado (Associação Wyty-Cate, 2012, p. 5).

Saindo do Cerrado e indo para a Amazônia, incluo também como referência as considerações do agente agroflorestal e, na época, secretário da Associação do Movimento dos Agentes Agroflorestais Indígenas do Acre (AMAAIAC), José de Lima Yube Kaxinawá, as quais introduzem a publicação Plano de Gestão Territorial e Ambiental da Terra Indígena Kaxinawá e Ashaninka do Rio Breu (CPI-AC, 2007):

A AMAAIAC vem trabalhando para que todas as terras indígenas do estado do Acre construam seus Planos de Gestão, porque acreditamos que ele é um documento muito importante para a gestão dos nossos territórios 
[...]. O Plano de Gestão é para ajudar a gente a continuar manejando e conservando a nossa biodiversidade de maneira que ela não se acabe, garantindo a nossa sobrevivência e a das futuras gerações. Ele também discute os problemas do entorno das terras indígenas e vem ajudando a organizar uma política melhor com os nossos vizinhos e com os municípios próximos às nossas terras. O Plano é um grande desafio para todos nós, índios e não índios, pois sua aplicação depende da compreensão das pessoas de que os recursos naturais se acabam se não forem manejados de uma maneira correta.

O Acre é um dos estados brasileiros que apresentam maior organização por parte dos povos indígenas, os quais logram apoio financeiro e postos na burocracia governamental, além do apoio de algumas instituições internacionais que veem neles importantes aliados na conservação da floresta amazônica. O Movimento dos Agentes Agroflorestais Indígenas do Acre pode ser considerado como a primeira grande experiência de sucesso de uma assistência técnica e extensão rural nativa, isto é, realizada por e segundo (ou em diálogo com) preceitos indígenas. Sobre o desafio pós-demarcatório, Yube Kaxinawá explica que:

Hoje em dia, a gente tem a necessidade de planejar o uso correto da nossa floresta. [...] Antes do contato com a sociedade ocidental, o nosso povo não tinha a necessidade de fazer "plano de gestão", porque nessa época havia muita fartura e não estávamos cercados por todos os lados de pessoas que usam a terra de uma forma muito diferente da nossa. Agora, as comunidades indígenas têm a necessidade de se organizar para fazer seus planos, para identificar quais são seus problemas e quais são as suas vantagens. Para nós, o plano de gestão não é uma lei, mas um acordo entre os grupos familiares, entre a comunidade, sobre como nós vamos cuidar da nossa terra, como vamos usar os recursos naturais, como vamos nos relacionar com os nossos vizinhos, como vamos trabalhar com o entorno, como vamos trazer um desenvolvimento que beneficie a todos: homens, mulheres, crianças, animais e plantas. Ele também não é uma proibição, mas um trabalho de conscientização com todos, índios e não índios. Com o passar do tempo, ele pode ser modificado, mas sempre com a participação de todo mundo para se chegar a um consenso com o objetivo único de cuidar com zelo e carinho do que é nosso (CPI-AC, 2007, p. 8).

Os planos de gestão têm sido uma ferramenta que vem ganhando cada vez mais adeptos entre os povos indígenas no Brasil, e vai adquirir 
contornos e finalidades peculiares em cada localidade. Eles não são documentos que encerram em si as soluções, mas são vistos como uma das possibilidades de se mediar diálogos internos e apoiar compromissos com agentes externos. Devem ser reelaborados de acordo com as mudanças que ocorrem.

Os planos de gestão são uma das formas encontradas de se materializar documentalmente as redefinições de controle social sobre os recursos naturais e bens culturais posteriores à demarcação, e também, de certa maneira, instigar avanços nessa matéria.

\section{Conclusões}

Neste artigo buscamos explorar conceitualmente um viés de continuidade para a síntese teórica para a reorganização social de grupos étnicos elaboradas pelo antropólogo João Pacheco de Oliveira, em especial quando está associada a conquistas de garantias fundiárias.

A partir da ideia sugerida, mas não aprofundada, pelo autor sobre a existência de um mecanismo de redefinição do controle social sobre os recursos ambientais como parte dos fatores associados ao fenômeno da reorganização social, passamos a explorar essa ideia, tentando amplificar seus usos ao mesmo tempo em que oferecemos também algumas delimitações de entendimento.

A partir deste exercício, concebemos a ideia de "redefinição do controle social sobre os recursos naturais e bens culturais" como fenômeno associado e intrínseco às etnogêneses e aos movimentos identitários socioterritoriais. Isto é, que deve ser entendida como parte da natureza de realização destes fenômenos, ainda que não seja possível estabelecer a priori características ou regras gerais, as quais deverão ser analisadas caso a caso.

De modo bastante pragmático, consideramos a ideia conceitualmente como um sinônimo da realização socioespacial de uma reorganização étnica ou comunitária, a qual institui novos contextos, significativamente distintos do anterior, sobretudo quando consegue intervir fortemente na estrutura agrária.

Portanto, entendemos como oportuna uma abordagem de pesquisa que logre olhar para elementos de ruptura, continuidade e reconstrução associados aos desafios de gestão dos territórios, um campo que ainda carece de aprofundamento, em especial, para os estudos de casos que têm utilizado o arcabouço teórico de Pacheco de Oliveira para análise dos índios do Nordeste.

A abordagem sobre a redefinição do controle social sobre os recursos naturais e bens culturais do momento pós-demarcatório pode contribuir para a redução de conflitos internos, bem como gerar subsídios para o apoio de agentes externos, sendo útil para a construção de planos de gestão ambiental e territorial comunitários. 
E por fim, chamamos atenção para o fato de que o contexto pósdemarcatório, por si só, remete a redefinições, e neste sentido, deve ser considerado como uma oportunidade por estudiosos, organizações e comunidades.

\section{Referências bibliográficas}

ALMEIDA, Alfredo Wagner Berno de. Os quilombolas e a base de lançamento de foguetes de Alcântara: laudo antropológico. Brasília: Edições Ibama, 2006.

Terras tradicionalmente ocupadas: terras de quilombo, terras indígenas, babaçuais livres, castanhais do povo, faxinais e fundo de pasto. Manaus: Ed. UFAM, 2008.

Territórios e territorialidades específicas na Amazônia: entre a "proteção" e o "protecionismo". Caderno CRH, Salvador, v. 25, n. 64, p. 63-71, jan./abr. 2012.

ARAÚJO, André Luis de Oliveira; ORDONIO, Iran Neves. Feira Xukuru do Ororubá: conquistas em torno de uma experiência de comercialização de alimentos de base ecológica. Cadernos de Agroecologia, Rio de Janeiro, v. 6, n. 2, 2011.

ARRUTI, José Maurício Andion. A emergência dos "remanescentes": notas para o diálogo entre indígenas e quilombolas. Mana, Rio de Janeiro, v. 3, n. 2, p. 7-38, out. 1997.

. A árvore Pankararu: fluxos e metáforas da emergência étnica no sertão do São Francisco. In: OLIVEIRA, João Pacheco de (org.). A viagem da volta. Rio de Janeiro: Contra Capa/LACED, 2004. p. 229-278.

ASSOCIAÇÃO WYTY-CATE. Associação dos Povos Timbira do Maranhão e Tocantins e Centro de Trabalho Indigenista. Plano de Gestão Territorial e Ambiental das Terras Indígenas Timbira Hempejxa Ampô Pje Inpej. Uberlândia: CTI, 2012.

BALANDIER, Georges. La situation coloniale: approche théorique. Cahiers internationaux de sociologie, v. 11, p. 44-79, 1951.

BARBALHO, Nelson. Caboclos do Urubá: caminhos e personalidades da história de Pesqueira. Recife: Biblioteca Pernambucana de História Municipal, 1977.

BARTOLOME, Miguel Alberto. As etnogêneses: velhos atores e novos papéis no cenário cultural e político. Mana, Rio de Janeiro, v. 12, n. 1, p. 39-68, abr. 2006.

BARBOSA DE ALMEIDA, Mauro W. Direitos à floresta e ambientalismo: seringueiros e suas lutas. Revista Brasileira de Ciências Sociais, São Paulo, v. 19, n. 55, p. 33-53, jun. 2004. 
BARRETO FILHO, Henyo Trindade. Invenção ou renascimento? Gênese de uma sociedade indígena contemporânea no Nordeste. In: OLIVEIRA, João Pacheco de (org.). A viagem da volta. Rio de Janeiro: Contra Capa/LACED, 2004. p. 93-137.

BARTH, Frederik. O guru, o iniciador e outras variações antropológicas. Tradução de John Cunha Commerford. Rio de Janeiro: Contracapa Livraria, 2000.

BIDASECA, Karina. La disputa es por el tiempo. Presencias/ausencias en la cuestión indígena en la Argentina. Revista Latinoamericana Pacarina de Ciencias Sociales y Humanidades, Salta, n. 0, p. 58-72, set. 2010.

BIRNBAUM, Pierre. Conflitos. In: BOUDON, Raymond (org.). Tratado de Sociologia. Rio de Janeiro: Ed. Jorge Zahar, 1995. p. 247-282.

BOMBARDI, Larissa Mies. O bairro rural como identidade territorial: a especificidade da abordagem do campesinato na geografia. Revista Agrária, São Paulo, n. 1, p. 55-95, 2004.

BONFIL BATALLA, Guillermo. La teoría del control cultural en el estudio de procesos étnicos. Estudios sobre las Culturas Contemporaneas, Colima, v. 4, n. 12, p. 165 204, 1991.

BOURDIEU, Pierre. Une classe objet. Actes de la recherche, Paris, n. 17, p.2-5, 1977.

CARDOSO DE OLIVEIRA, Roberto. O índio e o mundo dos brancos: a situação dos Tukúna do Alto Solimões. São Paulo: DIFEL, 1964.

COMISSÃO PRÓ-ÍNDIO DO ACRE (CPI-AC). Plano de Gestão Terra Indígena Kaxinawá e Ashaninka do Rio Breu. GAVAZZI, R. A. (org.). Rio Branco: Comissão Pró-Índio do Acre, 2007.

DIEGUES, Antonio Carlos. Repensando e recriando as formas de apropriação comum dos espaços e recursos naturais. In: DIEGUES, Antonio Carlos (org.). Espaços e recursos naturais de uso comum. São Paulo: NUPAUB-Núcleo de Apoio à Pesquisa sobre Populações Humanas e Áreas Úmidas Brasileiras, USP-São Paulo, 2001. p. 97 124.

DURKHEIM, Émile. As regras do método sociológico. Coleção Tópicos, Tradução Paulo Neves, $3^{\text {a }}$ ed. São Paulo: Martins Fontes, 2007.

FERNANDES, Bernardo Mançano. Movimentos socioterritoriais e movimentos socioespaciais: contribuição teórica para uma leitura geográfica dos movimentos sociais. Nera, Presidente Pruente, v. 8, n. 6, jan./jun. 2005. Disponível em:

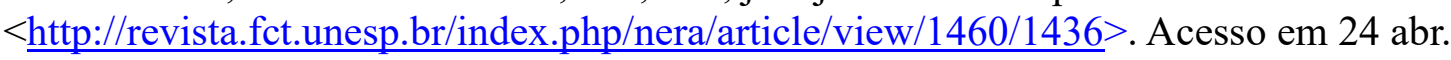
2017. 
La ocupación como una forma de acceso a la tierra en Brasil: una contribución teórica y metodológica. In: MOYO, Sam; YEROS, Paris (orgs.). Recuperando la tierra: el resurgimiento de movimientos rurales en África, Asia y América Latina, Buenos Aires, Argentina: CLACSO. p. 1-25, 2008. Disponível em: $<$ http://bibliotecavirtual.clacso.org.ar/ar/libros/sursur/moyo/15Fernandes.pdf $>$. Acesso em 24 abr. 2017.

FERREIRA, Ivson; BRASILEIRO, Sheila; FIALHO, Vânia. Dossiê Chicão Xukuru: Terra Indígena Xukuru/PE (1988-1998): breve histórico de um conflito permanente. In: FIALHO, Vânia; NEVES, Rita de Cássia Maria; FIGUEIROA, Maria Carneiro Leão (orgs.). "Plantaram" Xicão: os Xukuru do Ororubá e a criminalização do direito ao território.. Manaus: PNCSA-UEA/UEA Edições, 2011. p. 16-51.

GARLET, Ivori; ASSIS, Valéria de. Desterritorialização e reterritorialização: a compreensão do território e da mobilidade Mbyá-Guarani através das fontes históricas. Revista de História, Dourados, v. 11, n. 19, p. 15-46, jan./jun. 2009.

GLUCKMAN, Max. Análise de uma situação social na Zuzulândia moderna. In: FELDMAN-BIANCO, Bela (org.). Antropologia das sociedades contemporâneas. São Paulo: UNESP, 2009. p. 237-364.

GORDILLO, Gastón; HIRSCH, Silvia. Movilizaciones indígenas e identidades en disputa en la Argentina. Buenos Aires: La Crujía, 2010.

GRÜNEWALD, Rodrigo de Azeredo. Os índios do descobrimento: tradição e turismo. Rio de Janeiro: Contra Capa, 2001.

Etnogênese e 'regime de índio' na Serra do Umã. In: OLIVEIRA, João Pacheco de (org.). A viagem da volta. Rio de Janeiro: Contra Capa/LACED, 2004. p. 139-174.

GUEDES, André Dumans. Lutas por terra e território, desterritorialização e território como forma social. Revista Brasileira de Estudos Urbanos e Regionais, Recife, v. 18, n. 1, p. 23-39, jan./abr. 2016.

HAESBAERT, Rogério. O mito da desterritorialização: do “fim dos territórios" à multiterritorialidade. Rio de Janeiro: Bertrand Brasil, 2004.

HOHENTHAL JR., W.D. Notes on the Shucurú Indians of Serra de Ararobá, Pernambuco, Brazil. Revista do Museu Paulista, São Paulo, v. 8, p. 93-166, 1954.

LAPENDA, Geraldo Calábria. O dialecto Xucuru. Doxa, Recife, ano X, n. 10, p. 11 23, 1962.

LAZZARI, Axel. Ya no más cuerpos muertos: mediación e interrupción en el reconocimiento ranquel. E-misférica performance and politics in the Americas, Nova Iorque, v. 4, n.2, p. 3-9, 2007. 
Autonomy in apparitions: phantom Indian, selves, and freedom (on the

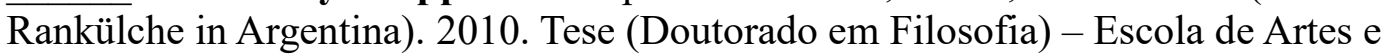
Ciências, Universidade de Columbia, EUA, 2010.

LENTON, Diana. Política indigenista argentina: una construcción inconclusa. Anuário Antropológico, Rio de Janeiro, v. I, p. 57-97, out. 2010.

LITTLE, Paul E. Espaço, memória e migração: por uma teoria de reterritorialização. Revista do Programa de Pós-graduação em História da UnB, Brasília, v. 2. n. 4, p. 5-25, 1994.

. Territórios Sociais e Povos Tradicionais no Brasil: por uma antropologia territorialidade. In: Simpósio Natureza e Sociedade: desafios epistemológicos e metodológicos para a Antropologia, 23 $3^{\mathrm{a}}$ Reunião Brasileira de Antropologia, Gramado, RS, v. 19, 2002. p. 2-31.

MATOS, Maria Helena Ortolan. O processo de criação e consolidação do Movimento Pan-Indígena no Brasil (1970-1980). 1997. Dissertação (Mestrado em Antropologia) Instituto de Ciências Humanas, Universidade de Brasília, Brasília, DF, 1997.

MAURO, Victor Ferri. Etnogênese e reelaboração da cultura entre os Krahô-Kanela e outros povos indígenas. Espaço Ameríndio, Porto Alegre, v. 7, n. 1, p. 37-94, jan./jun. 2013.

MONTE, Edmundo Cunha. Agreste pernambucano: gado, culturas agrícolas e os índios Xukuru do Ororubá. In: UFPE. XII Encontro de Ciências Sociais da UFPE, Recife, 9 -12 nov. 2010.

. Migrações Xukuru do Ororubá: memórias e história (1950-1990). 2012. 141 f. Dissertação (Mestrado em História) - Universidade Federal de Pernambuco, Recife, 2012.

MOURA, Marlene Castro Ossami de. Os tapuios do Carretão: etnogênese de um grupo indígena no estado de Goiás. Goiânia: Editora da UCG, 2008.

OLIVEIRA, Ariovaldo Umbelino de. A longa marcha do campesinato brasileiro: movimentos sociais, conflitos e reforma agrária. Estudos Avançados, São Paulo, v. 15, n. 43, p. 185-206, 2001.

. "Quem sabe faz a hora, não espera acontecer": o MST como movimento socioterritorial moderno. Revista USP, São Paulo, n. 64, p. 156-172, dez./fev. 2005.

OLIVEIRA, Kelly. E. de. Guerreiros do Ororubá: o processo de organização política e elaboração simbólica do povo indígena Xukuru. 2006. 218 f. Dissertação (Mestrado em Sociologia) - Programa de Pós-Graduação em Sociologia - Universidade Federal da Paraíba - UFPB. João Pessoa, 2006. 
PACHECO DE OLIVEIRA, João. Uma etnologia dos "índios misturados"? Situação colonial, territorialização e fluxos culturais. Mana, Rio de Janeiro, v. 4, n. 1, 47-77, abr. 1998.

Ensaios em Antropologia Histórica. Rio de Janeiro: Editora UFRJ, 1999.

Três teses equivocadas sobre o indigenismo (em especial sobre os índios do Nordeste). In: ESPÍRITO SANTO, Marco Antônio do (org.). Política indigenista: leste e Nordeste Brasileiros. Brasília: Funai/DEDOC, 2000. p. 17-26.

(org). A viagem da volta: etnicidade, política e reelaboração cultural no Nordeste indígena. Rio de Janeiro: Contra Capa/LACED, 2004a.

. Uma etnologia dos 'índios misturados'? Situação colonial, territorialização e fluxos culturais. In: PACHECO DE OLIVEIRA, João (org.). A viagem da volta. Rio de Janeiro: Contra Capa/LACED, 2004. p. 13-42b.

Hacia una antropología del indigenismo: estudios críticos sobre los procesos de dominación y las perspectivas políticas actuales de los indígenas en Brasil. Rio de Janeiro/Lima: Contracapa/Centro Amazónico de Antropología y Aplicación Práctica, 2006.

Sem a tutela, uma nova moldura de nação. In: OLIVEN, R.; RIDENTI, M.; BRANDÃO, G. (orgs.). 20 anos da Constituição Federal de 1988. São Paulo: ANPOCS/Hucitec, 2008. p. 251-275.

Regime tutelar e globalização: um exercício de sociogênese dos atuais movimentos indígenas no Brasil. In: REIS, D. A. et al (orgs.). Tradições e modernidades. Rio de Janeiro: Ed. FGV, 2010. p. 29-46.

PERES, Sidnei. Terras indígenas e ação indigenista no Nordeste (1910-67). In: OLIVEIRA, João Pacheco de (org.). A viagem da volta. Rio de Janeiro: Contra Capa/LACED, 2004. p. 43-92.

PORTO-GONÇALVES, Carlos Walter. Amazônia, amazônias. 2a ed. São Paulo: Ed. Contexto, 2005.

POZZOBON, Jorge. O lumpen-indigenismo do Estado brasileiro. Journal de la Société des Américanistes, Paris, tome 85, p. 281-306, 1999.

RAMOS, Alcida Rita. O índio hiper-real. Revista Brasileira de Ciências Sociais, São Paulo, n. 28, ano 10, p 5-14, jun. 1995.

Convivência interétnica no Brasil: os índios e a nação brasileira. Série Antropologia, $\mathrm{n}^{\circ}$. 221. Brasília: DAN/UNB, 1997. 
RIBEIRO, Darcy. Os índios e a civilização. Rio de Janeiro: Editora Civilização Brasileira, 1970.

RICARDO, Beto; RICARDO, Fany. Povos Indígenas no Brasil: 2011-2016. São Paulo: Instituto Socioambiental, 2017.

SANTOS, Milton. A natureza do espaço: técnica e tempo, razão e emoção. São Paulo: Edusp, 2006.

SILVA, Edson Hely. Xucuru: memórias e história dos índios da Serra do Ororubá (Pesqueira/PE), 1959-1988. 2008. Tese (Doutorado em História) - Universidade Estadual de Campinas. Campinas, 2008.

SOUZA, José Luiz de; Da desterritorialização ao território simbólico: o caminho de uma sociedade indígena rumo ao seu território tradicional. Caminhos de Geografia, Uberlândia, v. 8, n. 23, p. 73-80, 2007.

SOUZA, Vânia Fialho. As fronteiras do ser Xukuru: estratégias e conflitos de um grupo indígena no Nordeste. 1992. Dissertação (Mestrado em Antropologia) Universidade Federal de Pernambuco, Recife, 1992.

SOUZA, Vânia Fialho et al. Nova Cartografia Social dos Povos e Comunidades Tradicionais do Brasil: Xukuru do Ororubá - PE. Manaus: UEA Edições, 2012.

SOUZA FILHO, Benedito; ANDRADE, Maristela de Paula. Patrimônio imaterial de quilombolas: limites da metodologia de inventário de referências culturais. Horizontes Antropológicos, Porto Alegre, v. 18, n. 38, p. 75-99, dez. 2012.

STOCKING JR., George W. Colonial Situations. In: STOCKING JR. George. W. (ed.). Colonial situations: essays on the contextualization of ethnographic knowledge. History of Anthropology, vol. 7. Madison: The University of Wisconsin Press, 1991. p. 3-8.

TEIXEIRA, Pery; COSTA, André Monteiro. Xukuru do Ororubá: introdução à demografía de um povo indígena. In: ABEP. XVIII Encontro Nacional de Estudos Populacionais, Águas de Lindóia, 2012. Disponível em: $<$ http://www.abep.nepo.unicamp.br/xviii/anais/files/ST4[694]ABEP2012.pdf $>$. Acesso em 24 abr. 2017.

Recebido em: 26/04/2018 * Aprovado em: 22/01/2019* Publicado em: 27/06/2019 